\title{
Remote Sensing 10th Anniversary Best Paper Award
}

\author{
Prasad S. Thenkabail ${ }^{(1)}$ \\ Editor-in-Chief, Research Geographer 15, United States Geological Survey (USGS), 2255, N. Gemini Dr., Flagstaff, \\ AZ 86001, USA; pthenkabail@usgs.gov
}

Received: 26 July 2019; Accepted: 29 July 2019; Published: 31 July 2019

Started in 2009, our journal will celebrate its 10th anniversary in 2019. Remote Sensing boasts a most recent Impact Factor of 3.406 (2017). To acknowledge our authors' support, we set the "Remote Sensing 10th Anniversary Best Paper Award" as one of the award categories in celebration of the 10th Anniversary of Remote Sensing in 2019. There are 10 awards, including one special award, two Rank 1 awards, three Rank 2 awards and four Rank 3 awards.

Nominations from all papers published from 2009 to 2018 were made by the Evaluation Committee and finally approved by the Editor-in-Chief (EiC), Dr. Prasad S. Thenkabail. Following a review process by the Evaluation Committee, 10 final winners were selected. The recipients of the "Remote Sensing 10th Anniversary Best Paper Award", in no particular order, are as follows.

\section{Special Award:}

- Title: Unmanned Aircraft Systems in Remote Sensing and Scientific Research: Classification and Considerations of Use [1] Authors: Adam C. Watts, Vincent G. Ambrosia and Everett A. Hinkley

\section{Rank 1 Award (certificate and $800 \mathrm{CHF}$ each):}

- Title: A Non-Stationary 1981-2012 AVHRR NDVI3g Time Series [2] Authors: Jorge E. Pinzon and Compton J. Tucker

- Title: Advances in Remote Sensing of Agriculture: Context Description, Existing Operational Monitoring Systems and Major Information Needs [3] Authors: Clement Atzberger

\section{Rank 2 Award (certificate and $600 \mathrm{CHF}$ each):}

- Title: An Automated Technique for Generating Georectified Mosaics from Ultra-High Resolution Unmanned Aerial Vehicle (UAV) Imagery, Based on Structure from Motion (SfM) Point Clouds [4] Authors: Darren Turner, Arko Lucieer and Christopher Watson.

- Title: An International Comparison of Individual Tree Detection and Extraction Using Airborne Laser Scanning [5] Authors: Harri Kaartinen, Juha Hyyppä, Xiaowei Yu, Mikko Vastaranta, Hannu Hyyppä, Antero Kukko, Markus Holopainen, Christian Heipke, Manuela Hirschmugl, Felix Morsdorf, Erik Næsset, Juho Pitkänen, Sorin Popescu, Svein Solberg, Bernd Michael Wolf and Jee-Cheng $\mathrm{Wu}$

- Title: Global Data Sets of Vegetation Leaf Area Index (LAI)3g and Fraction of Photosynthetically Active Radiation (FPAR)3g Derived from Global Inventory Modeling and Mapping Studies (GIMMS) Normalized Difference Vegetation Index (NDVI3g) for the Period 1981 to 2011 [6] Authors: Zaichun Zhu, Jian Bi, Yaozhong Pan, Sangram Ganguly, Alessandro Anav, Liang Xu, Arindam Samanta, Shilong Piao, Ramakrishna R. Nemani and Ranga B. Myneni

4. Rank 3 Award (certificate and $400 \mathrm{CHF}$ each):

- Title: Persistent Scatterer Interferometry (PSI) Technique for Landslide Characterization and Monitoring [7] Authors: Veronica Tofani, Federico Raspini, Filippo Catani and Nicola Casagli 
- Title: A Review of the Application of Optical and Radar Remote Sensing Data Fusion to Land Use Mapping and Monitoring [8] Authors: Neha Joshi, Matthias Baumann, Andrea Ehammer, Rasmus Fensholt, Kenneth Grogan, Patrick Hostert, Martin Rudbeck Jepsen, Tobias Kuemmerle, Patrick Meyfroidt, Edward T. A. Mitchard, Johannes Reiche, Casey M. Ryan and Björn Waske

- Title: Remote Sensing of Coral Reefs for Monitoring and Management: A Review [9] Authors: John D. Hedley, Chris M. Roelfsema, Iliana Chollett, Alastair R. Harborne, Scott F. Heron, Scarla Weeks, William J. Skirving, Alan E. Strong, C. Mark Eakin, Tyler R. L. Christensen, Victor Ticzon, Sonia Bejarano and Peter J. Mumby

- Title: The EnMAP Spaceborne Imaging Spectroscopy Mission for Earth Observation (doi:) [10] Authors: Luis Guanter, Hermann Kaufmann, Karl Segl, Saskia Foerster, Christian Rogass, Sabine Chabrillat, Theres Kuester, André Hollstein, Godela Rossner, Christian Chlebek, Christoph Straif, Sebastian Fischer, Stefanie Schrader, Tobias Storch, Uta Heiden, Andreas Mueller, Martin Bachmann, Helmut Mühle, Rupert Müller, Martin Habermeyer, Andreas Ohndorf, Joachim Hill, Henning Buddenbaum, Patrick Hostert, Sebastian Van der Linden, Pedro J. Leitão, Andreas Rabe, Roland Doerffer, Hajo Krasemann, Hongyan Xi, Wolfram Mauser, Tobias Hank, Matthias Locherer, Michael Rast, Karl Staenz and Bernhard Sang

We believe these 10 exceptional papers represent valuable contributions to Remote Sensing and the scientific literature. On behalf of the Evaluation Committee and the Editorial Board of Remote Sensing, we would like to congratulate these teams for their excellent work. In recognition of their accomplishment, these team will be awarded prizes of $1000 \mathrm{CHF}, 800 \mathrm{CHF}, 600 \mathrm{CHF}$ and $400 \mathrm{CHF}$, respectively, and the privilege of publishing an additional paper of their choice free of charge in open access format in Remote Sensing, after the usual peer-review procedure.

Evaluation Committee:

Editor-in-Chief

Prof. Dr. Prasad S. Thenkabail

Research Geographer 15, United States Geological Survey (USGS), Flagstaff, AZ 86001, USA

E-Mail: pthenkabail@usgs.gov

Section Editor-in-Chief Editors

Dr. Richard Gloaguen

Helmholtz Institute Freiberg, TU Bergakademie Freiberg, D-09599 Freiberg, Germany

E-Mail: r.gloaguen@hzdr.de

Prof. Dr. Alfredo R. Huete

School of Environment, University of Technology Sydney, Ultimo, NSW 2007, Australia

E-Mail: alfredo.huete@uts.edu.au

Prof. Dr. Randolph H. Wynne

Department of Forest Resources and Environmental Conservation, Blacksburg, VA 24061, USA

E-Mail: wynne@vt.edu

Prof. Dr. Clement Atzberger

University of Natural Resources and Life Sciences (BOKU), Vienna, Austria

Email: clement.atzberger@boku.ac.at

Dr. Richard Müller

German Meteorological Service CM-SAF, Frankfurter Straße 135, 63067 Offenbach, Germany

Email: richard.mueller@dwd.de

Dr. Xiaofeng Li

NCWCP-E/RA3, 5830 University Research Court, College Park, MD 20740, U.S.A.

Email: xiaofeng.li@ieee.org 


\section{References}

1. Watts, A.C.; Ambrosia, V.G.; Hinkley, E.A. Unmanned Aircraft Systems in Remote Sensing and Scientific Research: Classification and Considerations of Use. Remote Sens. 2012, 4, 1671-1692. [CrossRef]

2. Pinzon, J.E.; Tucker, C.J. A Non-Stationary 1981-2012 AVHRR NDVI $3 g$ Time Series. Remote Sens. 2014, 6, 6929-6960. [CrossRef]

3. Atzberger, C. Advances in Remote Sensing of Agriculture: Context Description, Existing Operational Monitoring Systems and Major Information Needs. Remote Sens. 2013, 5, 949-981. [CrossRef]

4. Turner, D.; Lucieer, A.; Watson, C. An Automated Technique for Generating Georectified Mosaics from Ultra-High Resolution Unmanned Aerial Vehicle (UAV) Imagery, Based on Structure from Motion (SfM) Point Clouds. Remote Sens. 2012, 4, 1392-1410. [CrossRef]

5. Kaartinen, H.; Hyyppä, J.; Yu, X.; Vastaranta, M.; Hyyppä, H.; Kukko, A.; Holopainen, M.; Heipke, C.; Hirschmugl, M.; Morsdorf, F; et al. An International Comparison of Individual Tree Detection and Extraction Using Airborne Laser Scanning. Remote Sens. 2012, 4, 950-974. [CrossRef]

6. Zhu, Z.; Bi, J.; Pan, Y.; Ganguly, S.; Anav, A.; Xu, L.; Samanta, A.; Piao, S.; Nemani, R.R.; Myneni, R.B. Global Data Sets of Vegetation Leaf Area Index (LAI)3g and Fraction of Photosynthetically Active Radiation (FPAR)3g Derived from Global Inventory Modeling and Mapping Studies (GIMMS) Normalized Difference Vegetation Index (NDVI3g) for the Period 1981 to 2011. Remote Sens. 2013, 5, 927-948.

7. Tofani, V.; Raspini, F.; Catani, F.; Casagli, N. Persistent Scatterer Interferometry (PSI) Technique for Landslide Characterization and Monitoring. Remote Sens. 2013, 5, 1045-1065. [CrossRef]

8. Joshi, N.; Baumann, M.; Ehammer, A.; Fensholt, R.; Grogan, K.; Hostert, P.; Jepsen, M.R.; Kuemmerle, T.; Meyfroidt, P.; Mitchard, E.T.A.; et al. A Review of the Application of Optical and Radar Remote Sensing Data Fusion to Land Use Mapping and Monitoring. Remote Sens. 2016, 8, 70. [CrossRef]

9. Hedley, J.D.; Roelfsema, C.M.; Chollett, I.; Harborne, A.R.; Heron, S.F.; Weeks, S.; Skirving, W.J.; Strong, A.E.; Eakin, C.M.; Christensen, T.R.L.; et al. Remote Sensing of Coral Reefs for Monitoring and Management: A Review. Remote Sens. 2016, 8, 118. [CrossRef]

10. Guanter, L.; Kaufmann, H.; Segl, K.; Foerster, S.; Rogass, C.; Chabrillat, S.; Kuester, T.; Hollstein, A.; Rossner, G.; Chlebek, C.; et al. The EnMAP Spaceborne Imaging Spectroscopy Mission for Earth Observation. Remote Sens. 2015, 7, 8830-8857. [CrossRef] 